\title{
Uvíznuti v nelegalitě
}

\author{
Mired in Illegality \\ Daniel Topinka
}

ABSTRACT The text deals with the invisible movement of illegal migrants seeking employment.

Their invisibility is dual. On the one hand some immigrants fall into the category of those upon whom illegality has been imposed, while on the other hand there exist illegal migrants who strive to be invisible. The latter, in order to become invisible, have developed a number of masking methods so that their movement cannot be traced. It is possible to distinguish between two contradictory types of invisible movement from the perspective of illegal employment-seeking migrants. The first is so-called "work on the move" and the second is "movement in hiding". Illegal migrants exercise all due care to remain illegal for as long as it is possible. Not having one's whereabouts revealed and not being sanctioned, both fall within successful invisible movement. Many a practice in social hiding has been developed in order to attain and/or retain this status. Becoming an illegal migrant requires the ability to adopt a set of practices, follow the rules of invisible movement and continuously learn how to be inconspicuous, invisible and how to remain as such for as long as possible.

KEY WORDS immigration, illegal migrants, labour migration, legality

\section{Úvod}

Naši lidé složitě přežívají, ti co se sem dostali. Na počátku to byla hrůza. Prosím Boha, abych se už nikdy do takové situace nedostala. U vás v Čechách je vyšší životní úroveň, u nás je... jsou tam bohatí, podle toho jak kdo může. Já si jen chci svým snažením dobýt slušný život, chci se ve svých třiceti pěti letech realizovat. Možná už je pozdě. Nechci nic špatného, nechci banditismus. Prostě chci jen v Čechách pracovat a žít, protože v mojí vlasti to nejde.

Slovy nelegální imigrantky uvádím text, který se zaměřuje na deskripci jedné perspektivy životního světa nelegálních pracovních imigrantů, jež jsou na území státu fyzicky přítomni, ale přitom zůstávají neviditelní. Jejich neviditelnost je dvojí. Na jednu stranu se jedná o imigranty, jimž je ilegalita připsána. Tomuto zneviditelnění se budu věnovat jen okrajově. Více mne zajímá neviditelnost, o kterou usilují samotní aktéři nelegální migrace. Ti za účelem svého zneviditelnění vyvinuli a používají řadu maskovacích praktik. Tyto jejich praktiky se rozvinuly tam, kde se migranti pohybují z místa na místo. Imigranti vyvíjejí maximální úsilí, aby si zajistili a následně i udrželi práci. A k tomu je pohyb nezbytný - pracovat předpokládá práci aktivně vyhledávat a přitom se přemist'ovat z místa na místo. Pokud už je nějaká práce k dispozici, je třeba každý den do práce přijít a poté se patřičným zpo̊sobem pohybovat i na pracovišti. Tento pohyb je v prípadě imigrantů neviditelný a je pohybem ve skrytu. Pohyb je rovněž diverzifikován podle př́slušnosti imigranta $\mathrm{k}$ sociálnímu prostoru. Jak bude dále v textu podrobněji rozvedeno, prostor nelegality není substanciální, neoznačuje to, co sku- 
tečně existuje. Nelegálním migrantem se člověk nerodí, ale stává se jím až v zemi, kde, at' chce či ne, mu jsou připsány atributy nelegálního migranta. Nositelé nelegality navíc nejsou homogenní skupinou, jak se na první pohled může zdát, ale aktéry, kteří jsou vybaveni různou mírou sociálního a kulturního kapitálu, pochází z odlišného sociokulturního prostředí, z různých zemí původu.

Jak jsem naznačil, budu se blíže věnovat pohybu a praktikám zneviditelnění. Zaměřím se na jednu specifickou životní situaci, kterou budu dále nazývat situací uvíznutí. Jedná se o situaci, která byla velmi často tematizována $\mathrm{v}$ rozhovorech $\mathrm{s}$ nelegálními migranty, jež jsem analyzoval, a zaslouží si tudíž zvláštní pozornost. Obecně se jedná o migranty, kteří do České republiky přicestovali legálním způsobem, nějakou dobu v zemi legálně pobývali, vesměs pracovali nelegálně a po krátkém čase se propadli do nelegality a takzvaně v ní uvízli. Uvíznutí si nelze představit jako situaci, kdy jsou nelegální migranti odříznuti od jakýchkoliv kontaktů se světem legality a obývají parciální izolovaný svět. Nelegální imigrant není od legálního světa úplně oddělen a zproštěn všech kontaktů. Nelegální imigranti však tyto kontakty mnohdy shledávají jako ohrožující a vyhýbají se jim. Jejich zviditelnění („,vyzrazení“) ve světě legality s sebou nese riziko uvalení sankce, která spočívá ve vyhoštění ze země a představuje hrozbu nenaplnění účelu, za kterým migranti přicestovali. Situaci uvíznutí jsem se v následujícím textu rozhodl zdůraznit také z toho důvodu, že poukazuje na to, jak svět legality produkuje a kontroluje nelegalitu, a také na př́tomnost mocenských vztahů a jejich asymetrie. Situace uvíznutí rovněž umožňuje posoudit, do jaké míry je možné načrtnout mezi svět legality a nelegality ostrou dělící čáru. Cílem textu je však obeznámit čtenáře s explicitním pohybem nelegálních migrantů.

Z perspektivy nelegálních pracovních imigrantů lze v prostoru nelegality rozlišit dva protichůdné druhy „neviditelného“ pohybu.

Prvním je „rozpohybovaná práce“. Jejími iniciátory bývají zprostředkovatelé práce, jejichž servisu nelegální pracovníci využívají. K rozpohybovanosti také přispívá sezónní charakter vykonávaných prací - například v zemědělství či stavebnictví. Zprostředkovatelé používají strategii rozpohybované práce tam, kde se začínají objevovat známky možného zakořenění a sblížení se imigranta s okolím. Následuje jeho přemístění $\mathrm{k}$ jinému typu práce nebo do jiné ubytovny či bytu. Zprostřredkovatelé práce tedy po nějaké době iniciují přemístování nelegálních pracovníků a nechávají je tzv. „rotovat“ po různých pracovištích a ubytovnách.

Druhý typ „skrytého“ pohybu souvisí s již zmíněnou situací uvíznutí. Kontakty s prostředím legality jsou pro nelegální pracovní imigranty potenciálně ohrožující. Tito aktéři se obávají situace, kdy budou shodou náhod objeveni, identifikováni a následně sankcionováni vyhoštěním ze země. Maximální snahu po zneviditelnění provází praktiky sociálního ukrývání. Objevují se tam, kde se nelegální imigrant přemist'uje v prostoru - když vyhledává práci, pohybuje se na pracovišti, stýká se se spolupracovníky, navštěvuje své přátele a př́íbuzné, nakupuje či si čas od času vyrazí za zábavou. Nelegální migranti vyvíjejí maximální úsilí, aby v nelegalitě setrvali co nejdéle. Nebýt vyzrazen a sankcionován znamená umět se pohybovat neviditelně. Nelegální migranti vyvinuli nesmírné množství taktik vedoucích k sociálnímu ukrývání. Patří mezi ně pohyb v prostorech koncentrované anonymity a způsob života, který je považován za nenápadný. Důležité je co nejvíce splynout s okolím, zakrývat svou pracovní identitu a vyhýbat se kontaktům s reprezentanty legality. Pohyb 
nelegálních migrantů je pohybem ve skrytu, předpokládá dodržování řady pravidel a také neustálé učení se tomu, jak být nenápadným, neviditelným a jak v tomto stavu setrvat co možná nejdéle.

Předkládaný text si neklade za cíl popsat všechny aspekty sociálního světa nelegality. Zaměřuje se na popis pohybu nelegálních pracovních imigrantů, přičemž představuje perspektivu a zkušenosti aktérů - nelegálních migrantů. Je př́ispěvkem do diskuse týkající se nelegální pracovní migrace. $\mathrm{Z}$ teoretického hlediska text vychází ze sociálního konstruktivismu a z teze, že ilegalita migrantů je konstruována legálně (De Genova 2002). Neznámou zůstává, jak svou ilegální pozici vnímají sami aktéři nelegální pracovní migrace a jaké praktiky při svém zneviditelňování používají. Právě zde jsem se potýkal s etickým problémem - jak psát o praktikách těch, kteří je vyvinuli právě proto, aby jim umožnily se ukrývat? První možností by bylo o sociálním světě nelegálních migrantů nepsat vůbec, a tím pak ponechat stranou i studium ilegality. Druhou variantou je tyto praktiky v textu druhotně přejmenovávat a uvádět je $\mathrm{v}$ pozměněné podobě. Zvolil jsem tuto druhou možnost $-\mathrm{s}$ vědomím toho, že bez využití perspektivy každodennosti lze světu ilegality a jejím aktérům porozumět jen stěží.

Při psaní o životním světě nelegálních migrantů se nelze vyhnout alespoň rámcovému vymezení sociálního prostoru nelegality. V tomto směru si kladu otázku, zdali je možné nelegalitu konceptualizovat. Následně se $\mathrm{v}$ textu věnuji otázce diverzifikace sociálního prostoru nelegality, v němž nalézám tř̌i významné shluky. $V$ rámci každého $\mathrm{z}$ nich jsem vybral jeden životní příběh nelegálního migranta, který se po krátkém období legálního pobytu propadl do sféry nelegality a uvízl v něm. $V$ př́bězích nelegálních migrantů se zaměřuji na jejich ,neviditelný pohyb“ a uvádím některé praktiky zneviditelnění.

\section{Koncept nelegální pracovní migrace}

Je možné nelegální pracovní migraci konceptualizovat? Úskalí, které je s takovýmto konceptem spojeno, se týká již zmiňované substanciality. Nelegalita není problematizovaná jako taková a do řady výzkumů vstupuje jako prvek, který existuje „přirozeně“. Nicholas P. De Genova uvádí, že studium ilegality je epistemologickým, metodologickým a politickým problémem. Cílem mého textu není diskutovat nelegalitu jako takovou, ale zaměřit se na každodennost imigrantů. Přesto je ale nutné brát $\mathrm{v}$ úvahu některé metodologické problémy spojené s vymezením nelegality.

Nelegální pracovní migrace je konstruována národním státem jako problém. Je výrazem právního statusu, který odkazuje na vztah nelegálního migranta ke státu. Nelegalita je přijímána z perspektivy národního státu jako nevyvratitelný fakt, protože „existuje“ (De Genova 2002). Důkazem této existence jsou nelegální pracovní migranti, kteř́ jsou čas od času zadrženi na stavbách nebo při zběžných kontrolách dokladů. Identita nelegálního migranta je v první řadě konstruována jako politická. Označení „nelegální pracovní migrant“ je právním konstruktem, který vyprodukoval národní stát (De Genova 2002). Pokud se poohlédneme nazpět do období konstituování národních států, postřehneme, jak velká pozornost byla věnována rozlišení těch, kteří se stali k pobytu na území státu oprávněni, a těch, kteří byli o tuto možnost připraveni. Nelegální migrace se tak formovala po boku občanství. Zatímco počátkem 19. století docházeli lidé za prací do Pruska víceméně bez omezení, koncem století již byl ustaven kontrolní a re- 
gulační systém operující s pojmy „registrační povinnost“ a „nucený návrat“. Vývoj národních států ovlivnil dějiny pracovní migrace: stát se stal protektorem státních př́slušníků a ochráncem vlastních pracovních sil vǔči těm cizím (Bade 2005).

De Genova píše, že realita každodennosti migrantů byla pokřivena tím, že byla prohlášena za totálně izolovanou. Nelegální migranti se stali součástí odděleného parciálního subsvěta. Sociální vědci prítomnost světa nelegality nijak nezpochybňovali a při studiu nelegality tak pracovali se stejnou substancí jako národní stát. Pohybovali se v diskurzivním řádu imigračních politik, a tím napomáhali vytvářet objektivitu nelegálních migrantů. Nezpochybňovali konstrukt ilegality, který je produktem práva a nelze ho ztotožnit s realitou jako takovou. Každé omezení, které je materializováno právem, se současně stává zdrojem nelegálních praktik. De Genova v této souvislosti píše o legální produkci migrantovy ilegality. Nahlédnutí do ilegality je možné prostřednictvím uvědomění si historicity a diferencovanosti tohoto nelegálního světa (De Genova 2002).

Koho právo označuje za nelegálního pracovního migranta? Je zřejmé, že fenomén nelegálního pobytu úzce souvisí s nelegální prací (Bade 2005). Za nelegální pracovní migranty označuje právní systém ty, kteří na území státu nelegálně pobývají a současně nelegálně pracují. Primární je v tomto ohledu porušování pobytových regulí. Jedná se osoby, které:

a) Pobývají na teritoriu státu v rozporu s právními předpisy, přičemž přišly o možnost na území státu pobývat legálně a této možnosti už nemohou využít ani v budoucnu (napřs. odmítnutí žadatelé o vízum, vyhoštění cizinci). Tito migranti bývají označováni za překročitele povolené doby pobytu, ilegální migranty („,overstayers“, „,sans-papiers“). Může jít také o př́pad osob, jež pobývají na území státu v rozporu s právními předpisy, mohou svůj pobyt legalizovat, ale nečiní tak (např. obnovení víza). Tito lidé bývají označováni za utajené, neregulérní („,clandestine“, „undocumented“), nebot' jejich cílem je vyhnout se zlegalizování pobytu.

b) Po dobu svého pobytu se živí prací, aktivně vyhledávají nelegální pracovní trh a většinu času na něm participují. Porušují tak právní předpisy v oblasti zaměstnanosti cizinců.

Pokud budeme na svět nelegality nahližž z perspektivy nelegálního migranta, musí se tento během svého zabydlování $v$ novém prostředí nějakým způsobem vypořádat $\mathrm{s}$ připsaným statusem a naučit se přežít a obezřetně se pohybovat v daném sociálním prostředí.

Nelegální migrant, přestože se ocitl na samotném dně společenské hierarchie, se může považovat za úspěšného. I ze všudyprítomné negativity lze vytěžit určitý prospěch. Výzkum mezi mexickými imigranty a jejich rodinami poukázal na významné kontradikce v životním světě nelegálních migrantů. Jocelyn Solis dává mnohost kontradikcí spojených $\mathrm{s}$ postoji vůči cizincům do souvislosti s růstem diverzity a variability v prostoru nelegální migrace. Zaměřuje se na porozumění místu nelegálních imigrantů ve světě, na jejich zkušenosti a způsoby ospravedlnění imigrantského statusu. Ukázalo se, že nelegální imigrantské identity jsou artikulovány v termínech moci a sociální nespravedlnosti. Nelegální imigranti se identifikují se skutečností, že jim jsou odepřena základní lidská práva. Děti imigrantů ztotožňují postavení svých rodičů s ekonomickým a sociálním postavením, zatímco jazyk považují za strukturu moci, která je identifikuje jako imigranty. Formování identity nelegálního migranta je závislé na každodenním životě, v němž může být nelegální status maskován, vytěsněn nebo jinak kompenzován. Identita je rekonstruována na základě individuálních zkušeností a aktivit (Solis 2004). Z výzkumu je patrné, že existuje řada způsobů, jak se se svým novým statusem smírit. 
Totéž se dá očekávat i u učení se novým způsobům přežití a umění neviditelně se pohybovat. Coutin vymezil několik dimenzí neexistence, které charakterizují sociální prostor nelegality. Zařadil mezi ně omezení fyzického pohybu, které provází vysoká míra podrobení se, či dokonce sociální smrt (De Genova 2002). Nelegální migranti jsou podle Coutina v pohybu omezováni a pohyb se podřizuje limitující životní situaci, která je spiše neexistencí než existencí.

Jak jsem zmínil výše, De Genova píše o nutnosti odmítnout substanciální povahu nelegální migrace (De Genova 2002). Nelegální migrace je produktem práva, které vstupuje do každodenního života imigrantů. Svět nelegality je konstruován historicky a je diferencován. Obě tyto perspektivy musím vzít při popisu neviditelného pohybu v úvahu.

Nelegální pracovní migrace je produktem imigračního práva. Obchází kritéria týkající se pobytu na území a podmínky účasti na trhu práce. Objevuje se v západní Evropě od konce devatenáctého století, kdy začaly vlády stanovovat imigrační kritéria a migranti je začali obcházet (Castles a Miller 1993). Někteří stanovená nařízení obcházeli zcela, jiní vstupovali do cílových zemí legálně a nelegálními migranty se stali až po nějaké době. Nelegální pracovní migranti jsou ve většině př́padů znevýhodněnou skupinou, které se nedostává pobytového práva a právní ochrany. Objevuje se tam, kde dochází ke snahám omezovat migrační proudy. Změny v nařízeních upravujících imigrační kritéria tak mohou tlačit dříve legálně pobývající cizince do situace nelegality. Nelegální pracovní migrace se stala běžnou součástí mnoha ekonomicky prosperujících zemí a často je tiše trpěna nebo dokonce podporována. „Vlády mohou tuto záležitost ignorovat nebo od ní odvrátit oči a vyhnout se tak nutnosti poskytovat sociální služby nebo právní ochranu“ (Castles a Davidson 2000a). Takovýto pohled na nelegální pracovní migraci přichází s myšlenkou, že tento typ migrace státu vlastně vyhovuje, protože flexibilně reaguje na potřeby trhu práce, poskytuje zásobu méně kvalifikované a většinou nedostatkové pracovní síly. V neposlední řadě umožňuje se této síly ve chvíli nepotřeby zbavit, bez nutnosti se dále starat o její osud.

V České republice lze z hlediska konstruování nelegální pracovní migrace nalézt dva historicky významné okamžiky. Prvním bylo zpřísnění imigrační politiky, které představovalo prrijetí restriktivního cizineckého zákona a nového azylového zákona s účinností $\mathrm{k} 1$. lednu 2000. V tomtéž období došlo k zavedení vízového režimu s Ukrajinou a také k príjetí omezujících opatření v oblasti zaměstnávání cizinců. Toto mělo za následek institucionalizaci pracovní migrace z Ukrajiny (Uherek 2001) a ztrátu víry cizinců v možnost získání zaměstnání legální cestou (Livinský a Kočík 2003). Druhým okamžikem byla změna systému zaměstnávání v roce 2004 v souvislosti se vstupem ČR do Evropské unie. Cizinci tak byli rozděleni do dvou kategorií - na občany států EU a na ty, kteří občany států EU nejsou. První kategorie má vstup na trh práce volný, pro druhou kategorii a jejich zaměstnavatele platí určité podmínky (udělení povolení k zaměstnání na konkrétní pracovní místo, povolení k pobytu a povolení získávat zaměstnance ze zahraničí na volná pracovní místa). Zaměstnávání cizinců může mít dvě podoby: cizinec je bud' zaměstnán u právnické či fyzické osoby, nebo může sám podnikat. Cizinci, kteří jsou označeni za nelegální pracovní migranty, ale tyto podmínky z různých důvodů nesplňují. Zákon č. 435/2004 Sb., o zaměstnanosti, který upravuje zabezpečování státní politiky zaměstnanosti, definuje nelegální práci jako práci, kterou cizinec nevykonává pro právnickou nebo fyzickou osobu na základě pracovněprávního vztahu nebo jiné smlouvy, nebo ji vykonává v rozporu s vydaným povolením k zaměstnání nebo bez tohoto povolení, je-li podle zákona povolení k zaměstnání vyžadováno. 


\section{Diverzifikace prostoru nelegality}

Nyní se vrátím k poznámce o diferencovanosti nelegální pracovní migrace. De Genova uvádí, že substanciální uchopení světa nelegality vede k homogennímu vnímání tohoto světa. Ve skutečnosti je tento prostor velmi pestrý a diverzifikovaný. Tuto heterogenitu je nutné vzít do úvahy, pokud nechceme vytvářet výhradně jeden ideálně typický obraz nelegálního migranta, jenž zdaleka nevystihuje mnohotvárnost světa nelegality. Existuje způsob, jak takovouto diverzifikaci alespoň rámcově zachytit?

Při hledání odpovědi na tuto otázku jsem vyšel z analýzy dvaceti rozhovorů s imigranty, kteří měli v době pořizování rozhovorů v České republice status nelegálních pracovních migrantů, nebo měli tento status v nedávné minulosti, a to déle než jeden rok. Rozhovory byly pořízeny s cílem popsat strukturu prostředí a životní podmínky nelegálních pracovních imigrantů. Předmětem zkoumání byli nelegální pracovní imigranti se zkušeností s prací na teritoriu ČR delší než jeden rok, kteří přišli ze zemí, které nejsou členskými zeměmi EU. Předpokládal jsem, že existuje více typů nelegálních migrantů, které se vyznačují společnými znaky. Pro jednoduché rozlišení nelegálních migrantů jsem použil metodu shlukové (klastrové) analýzy a také faktorovou analýzu. Obě metody umožňují statisticky pracovat s kvalitativními daty. První, shluková metoda uspořádává objekty nebo proměnné do různých kategorií, a to na základě jejich podobnosti a nepodobnosti. Umožnila nalézt tzv. shluky, které se vzájemně podobají, a tím i kategorizovat konverzační partnery. Na základě rozhovorů jsem vybral dvacet znaků, které zachycovaly odlišnosti v životě imigrantů. Mezi ně patřil např́íklad ekonomický důvod odchodu ze země původu, využití služeb zprostředkovatele práce, zkušenost s vyzrazením z nelegality, internace v Zařízení pro zajištění cizinců, střídání nelegální práce, délka pobytu v zemi nad dva roky, opakované návraty domů, prrítomnost blízkých osob, představa o déletrvajícím pobytu a další. U každého znaku jsem zaznamenal jeho výskyt. Explorační faktorová analýza umožnila interpretovat faktory podle toho, jaké proměnné př́islušný shluk obsahuje.

Tímto zpo̊sobem se mi podařilo popsat trri shluky, pro které jsem hledal patřičné označení. Bylo by chybou tyto shluky zaměňovat za realitu jako takovou, spíše ilustrují, jak je nelegální pracovní migrace v Česku přibližně diverzifikovaná.

Do prvního shluku patři Individualisté. Jedná se o pracovní migranty, kteří zemi původu opustili z důvodu obav o svůj život a na delší dobu se jim uzavřela možnost návratu zpět. Nějakou dobu se pohybovali ve sfére legality, ale $\mathrm{z}$ různých důvodů byli o legalitu svého pobytu připraveni. Zlepšení ekonomické situace není a nebylo hlavním účelem jejich pobytu v Česku, do země je přivedl pocit ohrožení. Okolnosti jejich odchodu ze země byly dramatické, ale nespadají pod žádný z bodů Ženevské konvence, což by mohlo vést k získání azylu. Práci považují za způsob, jak se uživit a jak v novém prostředí přežít. Individualisté se vyhýbají jakékoliv závislosti na zprostředkovatelích práce a odmítají vstoupit do nerovného vztahu. Částečně je k tomu vede špatná zkušenost $z$ domova se světem „mafií“ a také představa odpovědnosti za svůj osud. Nazývám je Individualisty, protože se považují za samostatné osobnosti, které se o sebe dokáží postarat samy bez podpory zprostředkovatelů práce. Získat nelegální práci je pro ně obtížné, musí se přesouvat z místa na místo. V Česku nikoho neznají a nemají zde žádné vazby. Tolerují jediný typ zprostředkování, kdy je zprostředkovatelem Čech, který má navíc osobní vztah k zaměstnavateli. Individualisté vykazují podnikatelské rysy a nechávají se zaměstnávat zejména v oblasti služeb. 
Druhý shluk tvoří pracovní migranti, které pronásleduje smůla. Budu je nazývat Podvedenými. Dostali se do situace, kdy byli zprostředkovatelem práce opakovaně podvedeni. Zprostředkování bylo často započato již v zemi původu, ale po prŕíjezdu migranti zjistili, že práce není zajištěná, nebo jim po několikaměsíční práci zprostředkovatel nevyplatil žádné peníze. „Dvakrát se mi zprostředkovatel vypařil. Tak jsem nedostal peníze asi za půl roku práce." Přestože jsou tito zprostředkovatelé vytlačováni profesionálnějšími aktéry, již poskytují záruky plnění dohod, stále se objevují př́ípady, kdy zprostředkovatel jedná podvodně. $\mathrm{K}$ typickým př́ípadům patří, že zprostředkovatel zmizí nebo se vymluví, třeba na nesolventnost či nespolehlivost českého partnera. V každém případě zůstává závazek nenaplněn, což vede frustrovaného imigranta $\mathrm{k}$ hledání nových zprostředkovatelů obdobného typu. Z hlediska genderu patři do skupiny Podvedených ve větší míře ženy.

Za Gastarbeitery si dovolím označit ty, kteří přichází do Česka organizovaně, mnohdy společně se svými sousedy a známými. Míři především za prací a výhradně se spoléhají na trvalejší vazbu na zprostředkovatele. Tento vztah je navázán již v zemi původu a v Česku je prolongován. Rodina zůstává doma, Gastarbeiter ji živí na dálku, pravidelně jí zasílá část vydělaných peněz. Gastarbeiteři nejeví velký zájem o život v Česku, jsou tak pracovně zatíženi, že nemají ani čas či sílu se dění kolem věnovat. Cyklicky se vracívají na krátké období domů. Tímto zpo̊sobem dokáží fungovat několik let. „Jezdí sem často, každý měsíc. Měsíc dva tady pracuje a pak jede na týden dva domů. “ Gastarbeiteři nejsou výhradně muži, do této skupiny patří i ženy. Tito pracovní migranti pracují převážně v zemědělství a ve stavebním průmyslu.

Tři uvedené shluky poukazují na skutečnost, že vedle klasické ,gastarbeiterovské“ pracovní migrace krátkodobějšího cirkulačního rázu nalezneme i další dvě odlišné kategorie. Na těchto kategoriích také vidíme, že pokud budeme hledat zřetelné oddělení světa legality a nelegality, legální a nelegální od sebe nelze zcela oddělit. Nejvíce separovaní jsou Gastarbeiteři. Udržují minimální kontakt s legálním okolím. Bud’ po něm netouží, nebo jim ho jejich způsob života znemožňuje. Nejvíce odpovídají termínu „,přesazené“ komunity. „Po práci jsem zašel někam do hospody na jídlo, dal si pivo, panáka a šel spát, bez odpočinku by se to nedalo zvládnout, bylo to dost tvrdé.“ Tito aktéři se přesto setkávají s Čechy, např́íklad ve zmíněné hospodě nebo v práci, kde se srovnávají s českými spolupracovníky. Individualisté jsou kategorií značně dynamickou, která se na vlastní pěst pohybuje v českém prostředí a hodně se od něj dokáže naučit. Postupně kumuluje sociální a kulturní kapitál, který hodlá v budoucnu zužitkovat. Jedná se o značně individualizovanou strategii, na rozdíl od kolektivní strategie Gastarbeiterů. Podvedení migranti jsou častými fluktuanty, mění prostředí, zprostředkovatele a druhy práce. Gastarbeiteři a také Podvedení jsou do nelegální sféry plně vtaženi, Individualisté mají ve srovnání s nimi přesahů do legality podstatně více.

\section{Uvíznutí v nelegalitě}

Z předchozích odstavců vyplývá, že nelegální pracovní migranti mají různé možnosti pohybu a že mají větší či menší potřebu se světu legality vyhýbat. Odtud pochází obezřetné praktiky zneviditelňování se. Abych respektoval diverzitu nelegálního sociálního prostředí, rozhodl jsem se popsat tři příběhy nelegálních pracovních migrantů, prričemž každý 
odpovídá jednomu výše představenému shluku, a tím poukazuje i na různorodost nelegality. Nelegální migrantka Radana patř́ mezi Gastarbeitery, Katja je Individualistkou a Stěpan je z řad Podvedených.

Všechny tři př́iběhy spojuje jedna okolnost. Tou je propad do prostoru nelegality a následné uvíznutí v něm. Propad představuje situaci, kdy je legální status zaměněn za nelegální a u všech tř́ aktérů má jednu konkrétní podobu: došlo $\mathrm{k}$ němu vypršením lhůty platnosti víza, což znamená, že všichni tři aktéři přicestovali do Česka legálně, a také v zemi omezenou dobu legálně pobývali. Okamžik vypršení turistického víza je kritickým okamžikem, který je zprostředkovateli práce bagatelizován. Jedná se však o moment, který nelze vrátit zpět. Jak zásadní je tato chvíle, poznají aktéři až v okamžiku, kdy si uvědomí své bezvýchodné postavení. Neexistuje totiž př́liš možností, jak se ze sféry nelegality vrátit zpět. Propad bývá vesměs definitivní. Jeden z mála mobilitních kanálů představuje podání žádosti o azyl (Topinka 2006). K němu pracovní migranti sáhnou v okamžiku, když jsou unaveni neustálým střídáním vysilujících prací nebo když se ocitnou v situaci ohrožení (zadržení policií, ocitnutí se v blízkosti páchané trestné činnosti, nemožnost nalézt práci nebo objevení se zdravotních komplikací). Uvíznutí není situací, v níž by docházelo k úplnému odříznutí migrantů od jakýchkoliv kontaktů se světem legality. Dochází však k tomu, že se v očích nelegálních pracovníků stanou potenciální kontakty ohrožujícími, nebot’ představují riziko sankcionování. Vyhoštění ze země je komplikací a popřením účelu, za kterým přicestovali.

Radaně je něco přes třicet let a pochází z Ruska. Její životní příběh stručně převyprávím. Doma zůstal její sedmiletý syn, ale nejezdí za ním často, rozhodně ne tak často jako její otec. Otec dojiždí za prací do Česka každý měsíc. Měsíc pracuje v České republice a pak se vydává zpátky do Ruska, aby si jeden dva týdny odpočinul. Jezdí tak již devátým rokem. Stejně to dělá i její bratranec. V její zemi není možné sehnat práci. I její kamarádka je už osm let v Česku, podařilo se jí tady vdát. Radanin muž se také vydal do Čech za prací. Byla za něj provdaná několik let, byl však pryč už celý rok a nechtěl se vrátit. Tak se pro něj vydala sama. Návštěva skončila šokem. Její muž se změnil, „lidé se jednoduše mění“. Muži se vrací jiní, než odešli. Ženy se „vdají, žijí na vsi, nosí šátek, chodí do kostela.“ Oči jí otevřela až její provdaná kamarádka. Její muž tvrdil, že tady jenom dře a nikam nechodí. Po př́ijezdu však zjistila, že skutečnost byla jiná. Její první př́ijezd do Česka skončil špatně, s manželem se pohádala, byl to pro ni šok. Vrátila se domů. Při této první návštěvě Česka zjistila, že dokáže snadno porozumět jazyku, protože je z poloviny stejný jako ten její. Po čase se vydala do Česka znovu, její manžel $\mathrm{v}$ té době přestal vydělávat a posílat domů peníze. Se sháněním práce neměla problém, ani se zajištěním sama sebe. Už věděla, co život v Česku obnáší, že je jiný a že i ona se musí chovat jinak. V Česku „se mi líbí, protože zde jde normálně pracovat. Když je práce, jsou peníze... Tady se cítím člověkem, protože mohu vydělávat.“

Druhá návštěva Radany byla zaměřena na práci. Věděla, jakým způsobem se práce shání, a také, jaké jsou podmínky nelegálního pracovního vztahu. Začala pracovat záhy po svém př́ijezdu, ještě když měla turistické vízum. V jejím vyprávění ale tato okolnost zaniká. Soustřed’uje se jen na práci a pokud jí má, tak legalitu pobytu nepovažuje za důležitou. Nelegální práce je zkrátka spojená s nelegálním pobytem. Radana se pohybuje po území státu $\mathrm{s}$ obavami, ty jí přesto nebrání $\mathrm{v}$ tom, aby navštívila svou dlouholetou př́telkyni nebo otce. Musí pritom překonat vzdálenosti stovek kilometrů. Během cesty je vhodné nebudit nijak 
pozornost. Nemá význam, aby se chovala tak jako doma nebo aby se tak dokonce oblékala. Kdyby si na hlavu nasadila ušanku, tak každý pozná, odkud je. Radana se tak rychle vzdává tradičních zvyků. Také cestuje sama a vyhýbá se svým krajanům. Kdyby s nimi začala hovořit, tak lze také poznat, odkud pochází. Své krajany pozná na dálku - a rychle se jim vyhne. Když vstupuje na nádraží, porozhlédne se, kdo v hale postává. Navíc stejně nevěrí lidem, které zná jen zpovzdálí. Na autobus či vlak čeká společně s ostatními cestujícími, nedává se do řeči s cizími lidmi. Důvěřuje skutečně jen těm nejbližším, kteří se osvědčili. Bydlí ve velkoměstě. První práci si sehnala přes zprostředkovatelku práce - krajanku. Ta jí zajistila práci ve velkém stravovacím podniku, který má mezinárodní renomé. Tam ji a také ostatní měl na starost Čech. Pracovala vždy ve večerních a nočních hodinách. Do práce cestovala hromadnou dopravou a pak to měla už jen tři minuty chůze. Podnik navštěvovalo množství cizinců, a tak se nemusela bát, že by ji někdo kontroloval. Na tato místa stejně kontroly nechodí, protože by si ani firma neprrála, aby někdo kontroloval doklady všech cizinců. Čech, který ji měl na starost, ji začal obtěžovat a také za práci nezaplatil. Vyplácel jí vždy přes den, kdy si dali sraz v obchodním středisku, často se tam vymlouval, že nedostal peníze a že žádné nemá. Když peníze nevyplatil, tak hledala práci jinde.

Několikrát zašla na burzu práce a podařilo se jí získat práci přes zprostředkovatele. Ale byly to jen krátkodobé práce, uklízela po zednících, $v$ soukromých bytech a na dalších místech. Pořád ji posílali někam jinam, často pracovala společně se svými krajankami, ale vlastně se s žádnou nestačila sblížit. Po telefonu se dozvěděla, na které zastávce má čekat, a pak ji odvezli s ostatními někam na stavbu. Nikdy nevěděla dopředu, kam jedou a co tam budou dělat. Musela tak pořád cestovat po městě, protože je do autokaru sbírali pokaždé na jiném místě. Také je vysadili, kde chtěli, a pak musela dlouho cestovat domů. Bydlela v bytě, ale její krajanky často bydlí na ubytovnách. Také tam chvíli bydlela, ale více jí vyhovoval byt, který sdílela s jinými ženami. Ty se často střídají, protože musí chodit za prací. Byt je útulnější než ubytovna. Musí v něm dodržovat pravidla, aby nevyvolaly nějakou zbytečnou stížnost. Ten, kdo je hlučný a odmítá pravidla respektovat, musí byt opustit. O tom rozhoduje bytná, která má vše na starost. Když přijde nová spolubydlící, vysvětlí jí, jak se věci mají. Bytná chodí také pracovat, současně vyřizuje spoustu věcí kolem bytu a zná různé zprostředkovatele. Některé spolubydlící navíc v noci pracují a ve dne spí, jiné to zase mají naopak. Radana neměla potřebu vyrážet někam za zábavou, občas to dělaly její spolubydlící, když šly někam na diskotéku. Ona si raději odpočinula a těšila se na neděli, kdy uvidí své blízké. Když bydlela na ubytovně, byl tam př́snější režim. Zprostředkovatel se staral o to, aby se soustředily na práci.

Radanina situace se zlepšila až ve chvíli, kdy se náhodou začala starat o sad. V této práci vydržela celé léto. Konečně si našla práci, která jí vyhovovala. Byla na čerstvém vzduchu a moc lidí tam nechodilo. Oblékala se do kalhot a nosila obyčejnou košili. Sad byl rozlehlý a pokud chtěla, mohla si i odpočinout, aniž by si toho někdo všimnul. Měla svůj klid a když oddělala svoje, nikdo se o ni nezajímal. Bavila se jenom s majitelkou sadu. Našla si nejlepší cestu do práce a časem se už vyznala $\mathrm{v}$ tom, kde chodí nebo postává policie. $\mathrm{V}$ neděli měla volno a navštěvovala svou kamarádku nebo otce a bratrance. Vše se změnilo jednoho dne, kdy ji na návštěvě u bratrance kontrolovala policie. Přišli na její neplatné doklady, a tak se po krátké poradě s otcem rozhodla požádat o azyl. Jinak by ji poslali domů. Takhle bude moci ve své práci po krátké odmlce pokračovat a nemusí se chvíli bát, že je bez dokladů. 
Katja pochází z Moldávie. Je svobodná a v zemi původu už nezůstal žádný její příbuzný. Pracovala jako zdravotní sestra, poté jako dealerka v oblasti zdravotnictví. Chtěla dosáhnout více, a tak si zř́dila malý obchod s ovocem. Bohužel přišla o své zboží a musela splácet dluh. Peníze neměla a přestala platit i místní mafii, která jí vyhrožovala a zbila. Po incidentu si sbalila svých pár věcí a přicestovala do Česka. Útěk plánovala a stihla si vyřídit všechny potřebné dokumenty. Chtěla se vrátit ke své profesi zdravotní sestry, což se jí podařilo. Nějakou dobu pracovala legálně v nemocnici, ale stejně jí dávali jen pomocné úkoly. Tuto práci sehnala tak, že se obrátila na lékařku z Moldávie, o které se vědělo, že v Česku pracuje. Ta jí pomohla. V nemocnici pracovala od šesti do dvou hodin, měla vyřízené pracovní povolení. Večer se přesunula do supermarketu, kde pracovala na dvě směny až do jedné hodiny ráno. Přestože byl pracovní týden velmi náročný, víkendy Katje zůstávaly volné. Dokázala jich využít. „No, byly takové momenty, kdy bylo volno, a to jsme jezdili všude možně - třeba do ZOO, do kostelů. Protože to bylo v létě, tak ke mně přijižděla děvčata, která přijela dř́ive a tady to trochu znala. A tak jsme jezdily na výlety.“ Zatímco Radana se svým krajankám vyhýbala, Katja je aktivně vyhledává a seznamuje se s nimi. Dříve se neznaly a legální pobyt a práce jim umožňuje se volně pohybovat a poznávat hostitelské prostředí. Přesto se Katja obává mafiánů, kterým doma zůstala dlužna. Ví, že ji hledají, a tak se nemůže vrátit. Přišlo ale špatné období. Začalo tím, že dostala v nemocnici výpověd', protože se nedokázala naučit dobře česky. Ze dne na den tak přišla i o bydlení a musela se přestěhovat na ubytovnu. Následně přišla i o vízum a začalo její období několikaměsičního protloukání se. Morálně jí tato zkušenost nijak neublížila, ale změnil se její život. Narazila na lidi, kteř́ ji začali vydírat, protože věděli, že je zde neoficiálně a nemůže se obrátit o pomoc na policii. Věděli, ,že nikam nepoběžím a nebudu si stěžovat“. Legální práce i pobyt byly jednodušší. Ted' nemohla jít, kam se jí zachtělo, a pořád musela sledovat lidi, kteří se kolem ní objevovali. Několikaměsíční pobyt v ilegalitě nesla Katja velmi tě̌̌ce. Vytratily se její kamarádky, snažila se sehnat si práci sama. Odmítala využít zprostředkovatele, protože se nechtěla stát závislou a prohlubovat své dluhy. Nechce si jen vydělat, ale zůstat v Česku natrvalo a možná i začít studovat. Její neoficiální pobyt, jak zmiňuje, je tomu všemu překážkou. Uvědomuje si složitost své situace - nemůže se vrátit domů, ale také se už nemůže zapojovat do běžného života jako dřive. Kdyby byla Češkou, tak se nikdy nedostane do takovéto situace.

Katja je př́kladem dosti dramatického propadu do světa nelegality. Po propadu se musí učit novým způsobům přežití. Jistá práce $\mathrm{v}$ nemocnici, kterou kombinovala s přivýdělkem v supermarketu, je nenávratně pryč. Na novou situaci reagovala tak, že okamžitě uzpůsobila svůj standard a náklady svým možnostem - prestěhovala se na ubytovnu. Řada žen, zejména těch starších, ubytovnu téměř neopouští. Výjimkou jsou drobné nákupy, ale „,...ony nemají za co utrácet, vlastně nemají co utrácet“. Nyní už nemůže využít pomoci svých nových přátel, ti zůstali ve světě legality a netrápí je problémy, které ona musí řešit. Zvolila značně riskantní, ale individualizovanou strategii vyhledávání nelegální práce přímo, bez pomoci zprostředkovatelů. Hledání práce pro ni představuje neustálé pochůzky, během nichž ztrácí mnoho času. Zjišţuje, že sehnat si práci není tak jednoduché. Naráží na nedůvěru českých zaměstnavatelů, kteří nelegální pracovníky sice rádi zaměstnávají, ale vyjednávají spíše se zprostředkovateli nebo zprostředkovatelskými firmami, než s neznámými jednotlivci. Katja se učí pravidlům, jak oslovovat české zaměstnavatele, jak se nabízet, přesto cítí, že je její strategie málo efektivní. Pohybuje se z místa na místo, časem se naučila vyhledávat práci prímo $\mathrm{v}$ restauracích a barech. Tímto zpưsobem se ale dostává $\mathrm{k}$ jednorá- 
zovým pracím, po nichž sice dostane zaplaceno „na ruku“, ale musí jít zase někam jinam. Ví, že největšímu riziku se vystavuje v okamžiku, kdy vstoupí např́ílad do restaurace. Musí se rychle rozhlédnout kolem sebe a vyhodnotit, jestli jí nehrozí nějaké riziko. Očima prolétne hosty a vybírá, koho z obsluhujícího personálu osloví. Pokud se setká se špatnou reakcí, rychle vezme nohy na ramena a zmizí. Nejlepší je, pokud se podař́ oslovit př́mo majitele, $s$ kterým se dá domluvit někde „vzadu“. Nelegalita je pro Katju nečistým místem, stigmatizuje ji, což ale nemá vliv na její „morálku“. Její propad ukazuje, jak radikálně je omezen pohyb imigrantky, včetně participace na běžném životě. Nelegální migrant se nemůže vydat tam, kam chce - a pokud tak učiní, musí volit vhodný postup, aby se nevystavil nebezpečí vyzrazení.

Stěpan už v Česku pobývá pět let. Jeho příběh začíná doma na Kavkaze, když si začal shánět práci. Jednou do jejich vesnice dorazila skupina lidí, kteří nabízeli, že zajistí práci v Česku. Plácnul si s nimi a za pár týdnů mu zajistili vše potřebné. Nemusel se o nic starat. Věděl, jak do Česka pojede, a také co tady bude dělat. Měl zajištěné ubytování a všechno ho stálo jen pár korun. Začal pracovat na stavbě, „to je dost tvrdé, pracuje se minimálně tak dvanáct hodin denně.“ Výjimečně pracoval i sedmnáct hodin denně, někdy i v neděli. V neděli se pracovalo jen dopoledne. Volný čas Stěpan téměř neměl. Čechy poznával v práci, ale jen př́ležitostně. Po práci už neměl mnoho sil, a tak maximálně vyrazil do zapadlé hospody, kde se rychle najedl a šel spát. Jeho první práce neměla chybu. Sehnali ji ti zprostředkovatelé. Práce ale jednoho dne skončila, a tak se vydal shánět další práci na vlastní pěst. Nepochodil. Obcházel stavby, musel se vyptávat cizích lidí a nedařilo se mu nic sehnat. Pozoroval zpovzdálí, kdo je oblečen v civilu a toho pak oslovil. Bylo pravděpodobné, že se nejedná o Čecha, ale o zprostředkovatele. Vydal se tedy na místa, kde se vyskytovali zprostředkovatelé práce nebo ti, kteří na ně měli kontakt. Vyptával se v barech, na nádražích, burzách a byl úspěšný. Stačilo se obrátit na „našince“, který už nějaký ten kontakt měl.

Začal pracovat - zprostředkovatel zajistil veškerý servis. Najednou měl kde bydlet, zprostředkovatel zajištoval odvoz do práce a další služby. Za tyto služby sice platil, ale nic není zadarmo. Jednoho dne zprostředkovatel zmizel. Domáhal se s ostatními vyplacení mzdy u českého zaměstnavatele, ale ten jim řekl, že to není jeho věc. A tak prrišel o několikaměsiční mzdu. Za svůj pobyt vystřídal desítku pracovních míst, všechny byly spojeny se stavebnictvím. Na lepší místa, třeba „do fabriky pod střechu“, se nikdy nedostal. Podvedli ho třikrát, ale co si má počít? Jednou, když pracoval na stavbě, ho zatkla policie a byl internován v Zařizení pro zajištění cizinců. A tak přišel o další své peníze. Ještě poznámka ke Stěpanově dalšímu osudu - po svém zadržení a umístění do Zařízení pro zajištění cizinců požádal o azyl a vrátil se zpět do práce.

Stěpan nehledá jinou variantu existence než nelegální. Nelegální sféra pro něj skýtá některé výhody, je vysoce flexibilní, dokáže reagovat velmi pružně. Flexibilita spočívá v rychlém a snadném získání práce, o což jde především. Nelegalita snímá z imigrantů řadu zátěží spojených $\mathrm{s}$ organizací běžného života $\mathrm{v}$ neznámém prostředí a odstraňuje bariéry a překážky, které jsou především administrativního rázu. Zprostředkovatelé zajištují kompletní servis. Jeho obsah bývá různý. Vesměs tento balíček služeb zahrnuje přepravu do země, také do zaměstnání, ubytování a práci. „Někteř́ jsou dobří (zprostředkovatelé - pozn. D. T.) a postarají se o ubytování, seženou práci, půjčí peníze... zaplatí i ubytovnu, dopravu z ubytovny na stavbu.“ Komplexní servis je nelegálními migranty přijímán pozitivně. Odlehčení, které přináší, sice představuje vyšší náklady (za tyto služby se zprostředkovateli vyplácí přibližně třetina mzdy), ale současně 
umožňuje soustředit se výhradně na práci, plně se koncentrovat a nezatěžovat se organizačními záležitostmi či hledáním práce. Předností nelegální sféry je efektivita organizace života a práce a schopnost eliminovat překážky, které se zdají být nepřekonatelnými (jazyková bariéra, vyjednávání se zaměstnavateli, projevy nedůvěry českých zaměstnavatelů). V nelegální sfeerée se setkáváme spíše s rezignací na legalitu a nezájmem o ni. Stěpan k tomu říká: „Legálně? Nevím o nikom, kdo takhle pracuje, s nikým takovým jsem se nesetkal, jenom s ilegály..."

Stěpanova pracovní kariéra je přerušována nespolehlivostí zprostředkovatelů, občas také tím, že práce jednoduše skončí. Pohybuje se z místa na místo a naučil se vyhledávat zprostředkovatele. Ví, na jakých místech je nalezne - v barech, na nádražích, ubytovnách. Hledání práce je pro něj obtížným okamžikem, protože musí chodit po různých místech a vystavuje se riziku, že bude vyzrazen. Když má práci, pohybuje se mezi pracovištěm a ubytovnou. Přemístění zajišt’uje zprostředkovatel. Čas po práci věnuje především odpočinku na ubytovně. Zde panuje nepsaný řád - ubytovaní vesměs pracují pro jednoho zprostředkovatele, který se jich v př́padě problémů může zbavit, o což nemá nikdo zájem. Konflikty na sebe poutají zbytečnou pozornost, jako mediátor na ubytovně slouží vrátný. Zprostředkovatelé jsou neradi, když se jejich klienti pohybují mimo ubytovnu. Někdy dělají vše proto, aby klienti nemuseli moc vycházet ven - např́iklad dovezou potraviny. Zejména mladí pracovníci o víkendu vyráží za zábavou, vyhledávají diskotéky a bary. Pokud se zapletou do nějakého konfliktu, vystavují se riziku kontroly ze strany policie. Proto je lepší se držet stranou. Pokud se chce Stěpan s někým setkat mimo ubytovnu, volí nádraží nebo kavárnu, kde se pohybuje spousta lidí.

Stěpan má zkušenost s prací na stavbách. Některé opravy se dělají na obytných domech, a tak se nelegální pracovníci setkávají během dne s neznámými Čechy. Na Stěpanově pracovišti, kde pracovalo asi dvanáct nelegálních pracovníků, kteří tvořili asi devadesát procent všech dělníků, se nelegální pracovníci zdržovali ve volných chvílích ve vyhrazených sklepních prostorech nebo odpočívali na balkonech. Chvílemi jsem měl pocit, že na stavbě vlastně nikdo není. Stěpan mi vysvětlil, že nejde o zahálku, ale že vzhledem k dlouhé pracovní době nelze jinak, než během dne častěji odpočívat a využít k tomu každou chvilku, která se naskytne. Pokud pracovníci procházeli po společné chodbě, tak zrychlili krok a obyvatelům domu neodpovídali na pozdrav. Také jsem nezaslechl, že by na sebe pokřikovali, jak bývá na stavbách zvykem. Někteří mladší pracovníci se časem odvážili pohvizdovat na kolemjdoucí matky tlačící před sebou kočárek.

\section{Neviditelný pohyb}

Nelegální migranti usilují o to, aby nebyli vyzrazeni. Ti, kteří se do nelegality propadli a následně v ní i uvízli, nemají př́liš mnoho šancí, jak se z ní vymanit, a pohybují se tak, aby setrvali v nelegalitě co nejdéle. Nebýt vyzrazen a sankcionován znamená umět se pohybovat neviditelně. Nelegální migranti vyvinuli množství taktik sociálního ukrývání.

Neviditelný pohyb má dvě dimenze. První nazývám rozpohybovanou prací. Jejími iniciátory jsou zprostředkovatelé, jejichž služeb nelegální pracovníci využívají. Jakmile se začnou objevovat znaky možného zakořenění, je migrant přemístěn na jinou práci nebo do jiné ubytovny či bytu. Začleňování, byt' velmi nesystematické, je pro zprostředkovatele překážkou, nebot' nad svými klienty ztrácí kontrolu. Zprostředkovatelé práce sami po nějaké době iniciují přemíst’ování svých klientů. Nechávají je tzv. rotovat. „Nevím, kam mne odvezou a co 
tam bude. Žiju jen přítomností - jsem jako brouk, co ho ovládá nějaká větší síla." Nelegální pracovníci pak dokáží během roku vystřídat mnoho pracovních míst a poznat řadu krajanů či jiných cizinců. V tzv. Zprostředkovatelských bytech a ubytovnách jsou př́chody a odchody na denním pořádku. Je ustanoven vrátný, který jako jediný pobývá na místě trvale a zodpovídá za bezproblémové bydlení ostatních. Všichni ostatní se stř́idají. Rotace klientů je způsobena jak krátkodobým charakterem nekvalifikovaných prací, tak i záměrným působením zprostředkovatelů. Ti zabraňují vytvoření intenzivnějších vazeb $\mathrm{k}$ místu, lidem či okolí. K rotaci také přispívá charakter vykonávané práce, která je dočasná. „Většinou se nejedná o dlouhodobé zaměstnání, ale o nárazové akce a ty se velmi často stř́ídají.“

K pohybu jsou někteří nelegální pracovníci nuceni nepřetržitými změnami zprostředkovatelů. Pohyb je vnímán jako prostředek nalezení nového zprostředkovatele. „Pracovali pro zprostředkovatele a ten se na začátku měsíce ztratil, takže nedostali peníze za měsíc práce. Český zaměstnavatel řekl, že peníze dal zprostředkovateli a ten s nimi utekl, at’ si to tedy vyř́ídí s ním... co měli dělat? Jít na policii, když jsou tu nelegálně? Nebo dělat ramena na toho Čecha, aby on na ně zavolal policii? To ne, tak si život komplikovat nechtěli.“ Nezbývá nic jiného, než jít zkusit štěstí jinam. Nespolehlivost zprostředkovatelů klienty nutí vyhledávat ty spolehlivější. „Když nedostal peníze, tak se sebral a odstěhoval se jinam.“ V rámci těchto přesunů se rozvíjejí různé identifikační praktiky. Souvisí s nutností nalézt zprostředkovatele v rozlehlém a neznámém prostoru. Zprostředkovatelé jsou vyhledáváni na místech pravděpodobného výskytu. „Další možná cesta ke zprostředkovateli vedla přes stavby. Tam dojdete a pozorujete, jestli tam někdo dělá $\mathrm{v}$ civilu, jakože nemá montérky. Potom je jistota, že to není Čech. K tomu zajdete a požádáte jej o kontakt na klienta a máte vyhráno.“ Dalšími místy vyhledávání jsou nádraží, burzy, výstaviště, restaurace, bary a diskotéky.

Druhá dimenze pohybu má maskovací charakter. Pohyb se odehrává „ve skrytu“ a souvisí s již zmíněnou situací uvíznutí. Pohyb ve skrytu v sobě obsahuje omezení, přičemž roste význam referenčního místa, ke kterému se vztahují veškeré aktivity a dění. Referenčním místem je nejčastěji byt či ubytovna a pracoviště. Za nejvýznamnější místo považují nelegální migranti místo výkonu práce. Toto místo nemá geografický charakter, spíše se vztahuje k charakteru práce a pracovní náplni. Významnými místy mohou být pekárna, velkosklad, hotel, zahradnictví, nemocnice či statek. Druhým významným místem je místo pobytu, kde tráví klienti svůj volný čas a odpočívají. Jedná se o ubytovnu, kravín, maringotku nebo zprostředkovatelský byt. Dalšími referenčními body jsou místa kontaktu se zprostředkovatelem a také místa setkávání se s přáteli. K nim patř́ restaurace, prodejny se suvenýry a bary. Prostor je v nelegální migraci strukturován nikoliv etnicky, ale místně. Není parcelizován podle měst, čtvrtí, obvodů, bloků, ale podle konkrétních míst. Orientačním bodem na mapě je „náš bar“, ,naše nádraži““ atd. Výjimkou je oblast Karlových Varů, kterou považují migranti za výlučně „,ruskou zónu“.

Kontakty s prostředím legality jsou pro nelegální pracovní imigranty potenciálně ohrožující. Obávají se situace, kdy budou shodou náhod objeveni, identifikováni a následně sankcionováni vyhoštěním ze země. Maximální snahu po zneviditelnění provází praktiky sociálního ukrývání. Objevují se tam, kde se nelegální imigrant přemístuje v prostoru - vyhledává práci, pohybuje se na pracovišti, stýká se se spolupracovníky, navštěvuje své přátele a př́ibuzné, nakupuje a čas od času si vyrazí i za zábavou. Nelegální migranti jednají tak, aby nevzbuzovali zbytečnou pozornost, která by mohla ohrozit jejich setrvání v nelegalitě. Důležité je naučit se 
pohybovat neviditelně, a tím své setrvávání $\mathrm{v}$ ilegalitě prodloužit. Nelegální migranti vyvinuli nesmírné množství taktik vedoucích $\mathrm{k}$ sociálnímu ukrývání. Patří mezi ně pohyb v prostorech koncentrované anonymity (nádraží, kavárny, diskotéky) - nejlepší rozhovory se podařilo uskutečnit právě v kavárnách pobliž rušných náměstí a ulic. K ukrývání slouží i způsob života, který je považován za nenápadný: „vedl klidný domácký život, práce, nákupy, televize“. Jakoby se svět smrštil do malého privátního prostoru. Dưležité je „,do ničeho se nemíchat a o nic se nezajímat“. Nadměrný hluk, konflikty a pořádání večírků jen zbytečně přitahují pozornost. Večírky se proto pořádají v ,arabských klubech“, kam Češi nechodí, život v ubytovnách a bytech je organizován podle nepsaných řádů, na který dohlíži „,vrátni““. Důležité je co nejvíce splynout s okolím, zakrývat svou pracovní identitu a vyhýbat se kontaktům s reprezentanty legality. I na pracovišti jsou eliminovány zbytečné kontakty a minimalizován kontakt s okolím. Setkávat se se známými je možné na rušných náměstích, nádražích či v př̌plněných barech. Pohyb nelegálních migrantů je pohybem ve skrytu, předpokládá dodržování řady pravidel a také neustálé učení se tomu, jak být nenápadným, neviditelným a jak v tomto stavu setrvat co možná nejdéle.

Výjimečně splyne místo odpočinku s místem práce, jak je tomu v prŕípadě žen, které přespávají v budovách zemědělských statků, stavebních dělníků, kteří zůstávají přes noc v areálu rozestavěných staveb, nebo různých vrátných, kteří obývají maringotky s nářadím. Pohyb, který přesahuje tato místa, je nežádoucí. Zprostředkovatel zajišt'uje $\mathrm{v}$ rámci svého servisu i přepravu na místo výkonu práce, prí́padně i nákup a př́sun potravin na ubytovnu. Nelegální pracovníci tak nemají potřebu opouštět svá referenční místa. Zprostředkovatelé jim také často odeberou doklady, čímž prohlubují nezájem o pohyb „venku“. Také dohlíží na práci svých klientů, dbají na to, aby byla práce prioritní náplní dne a sankcionují jakékoliv rušení pracovního režimu. „Kdo nepracoval nebo se motal, tak o práci přišel. A mohlo se stát, že ji pak hưř sháněl.“ Veškerý život se odehrává mezi pracovištěm a ubytovnou.

Někteří nelegální migranti se běžně pohybují v českém prostředí, ale neustále vnímají nebezpečí vyzrazení, které s sebou přemístování nese. „Musí chodit po stavbách, ptát se cizích lidí, což samo o sobě může být riskantní.“ Také zde se objevují taktiky bezpečného vyhledávání práce. „V hospodě navázal kontakt s nějakými Čechy, ti mu dali kontakt na jiného Čecha a ten mu dal práci.“ Častěji než ostatní podstupují riziko, že budou odhaleni a umístěni do některého ze Zařízení pro zajištění cizincư, což se jim také čas od času stává. „Když člověk hledá sám práci, tak je to s nejistým výsledkem. Musí chodit, ptát se cizích lidí, což může být riskantní. Uvědomte si, že většinou nemáte v pořádku doklady, díky čemuž můžete skončit ve vězení pro cizince, tak jak se tomu stalo.“ Pokud chtějí pracovat, nemají na výběr a každý pohyb pro ně skýtá velké riziko. Omezení pohybu vnímají jako ztrátu autonomie, na kterou kladou velký důraz. Vyhýbají se zprostředkovatelům, kteř́ jsou cizinci: „...nenavštěvuje trhy práce, protože se nechce vázat na cizince“. Vyhledávají práci mezi Čechy, což je vede k závěru, že dostávají „lepší práci“, lépe placenou.

\section{Závěr}

V tomto textu jsem se zabýval neviditelným pohybem nelegálních pracovních migrantů. Jejich neviditelnost je dvojí. Na jednu stranu je zde fakt, že je imigrantům ilegalita připsána, já jsem se ale více věnoval neviditelnosti, o kterou usilují samotní aktéři nelegální migrace. Ti za účelem svého zneviditelnění vyvinuli a použivají řadu maskovacích praktik s cílem 
zakrýt svůj pohyb. Tento pohyb je neviditelný a je pohybem ve skrytu. Rovněž je diverzifikován podle př́slušnosti imigranta $\mathrm{k}$ sociálnímu prostoru, jak ukazují př́běhy Katji, Stěpana a Radany. Blížeji jsem se věnoval pohybu a praktikám zneviditelnění v situaci uvíznutí v nelegalitě. $Z$ perspektivy nelegálních pracovních imigrantů lze $\mathrm{v}$ prostoru nelegality rozlišit dvě dimenze neviditelného pohybu. Prvním je „rozpohybovaná práce“ a druhým pohyb „ve skrytu“. Nelegální migranti vyvíjejí maximální úsilí, aby v nelegalitě setrvali co nejdéle. Nebýt vyzrazen a sankcionován znamená umět se pohybovat neviditelně. Za tímto účelem vznikla řada taktik sociálního ukrývání. Stát se nelegálním migrantem vyžaduje umění osvojit si řadu praktik, dodržovat pravidla neviditelného pohybu: neustálé učení se tomu, jak být nenápadným, neviditelným a jak v tomto stavu setrvat co možná nejdéle. Ti, kteří v nelegalitě uvízli, jsou v možnostech fyzického pohybu silně limitováni.

\section{Literatura}

Bade, K. J. 2005. Evropa v pohybu. Evropské migrace dvou staletí. Praha: NLN.

Baršová, A.; Barša, P. 2005. Přistěhovalectví a liberální stát. Brno: Masarykova univerzita.

Bauman, Z. 1999. Globalizace. Praha: Mladá fronta.

Bauman, Z. 2002. Tekutá modernost. Praha: Mladá fronta.

Berger, P. L; Luckmann, T. 1999. Sociální konstrukce reality. Brno: CDK.

Castles, S. 2000a. Ethnicity and Globalization. London: SAGE Publications.

Castles, S.; Davidson, A. 2000b. Citizenship and Migration. London: Macmillan Press.

Castles, S.; Miller, M. J. 1993. The Age of Migration. New York: The Guilford Press.

Cizinci v České republice 2005. 2005. Praha: Český statistický úrad.

De Genova, N. P. 2002. „Migrant ,Illegality“ and Deportability in Everyday Life.“ Annual Review of Antropology, Vol. 31: 419-447. Palo Alto: Annual Reviews.

Drbohlav, D.; Janska, E.; Horakova, M. 2005. „Czech Republic.“ In J. Niessen, Y. Schibel, C. Thompson Current Immigration Debates in Europe: a Publication of the European Migration Dialogue. Brussels/Prague: MPG.

Drbohlav, D.; Janská, E. 2004. „Current Ukrainian and Russian Migration to the Czech Republic: Mutual Similarities and Differences." In A. Górny, P. Ruspini (eds.) Migration in the New Europe. Houndmills: Palgrave Macmillan.

Giddens, A. 1998. Di̊sledky modernity. Praha: Slon.

Guibernau, M.; Rex, J. 1997. The Ethnicity Reader. Cambridge: Polity Press.

Habermas, J. 2000. Problémy legitimity v pozdním kapitalismu. Praha: Filosofia.

Hayter, T. 2004. Open Borders. London: Pluto Press.

Lesthaeghe, R. (ed.) 2000. Communities and Generations. Brussels: VUB University Press.

Potírání obchodu s lidmi v ČR a možnosti optimalizace bezpečnostní politiky státu. 2006.

Praha: Ivan Gabal Analysis \& Consulting.

Sociální studia: Sociální exkluze a nové třídy. 2000. Brno: Masarykova univerzita.

Solis, J. 2004. „Narrating and Counternarrating Illegality as an Identity.“ In C. Daiute, C.Lightfoot (eds.) Narrative Analysis. London: SAGE Publications.

Topinka, D. 2006. „The Client's System in the Czech Labour Market: Brokers, Immigrants and

Employers.“ In K. Iglicka (ed.) Immigration Policies and Security. Warszawa: Center for International Relations. 
Van Gennep, A. 1996. Přechodové rituály. Praha: NLN.

Weber, M. 1998. Metodologie, sociologie a politika. Praha: Oikoymenh.

Internetové zdroje:

Černík, J. 2005. Klientský systém jako quasi-feudalismus v Česku. Praha: Multikulturní centrum [online]. Dostupný z: <http://www.migraceonline.cz>

Čižinský, P. 2006. Regularizace nelegální migrace v Evropě. Praha: Multikulturní centrum [online]. Dostupný z: <http://www.migraceonline.cz>

Fedyuk, O. 2006. Ukrajinští pracovní migranti: pohled prizmatem stereotypů. Praha: Multikulturní centrum [online]. Dostupný z: $<$ http://www.migraceonline.cz $>$

Horáková, M. 2005. Cizinci na trhu práce v České republice v letech 1994-2004. Praha: VÚPSV [online]. Dostupný z: <http://www.vupsv.cz $>$

Leontiyeva, Y. 2005. Ukrajinci $v \check{C} R$. Praha: Sociologický ústav AV ČR [online]. Dostupný z: $<$ http://www.socioweb.cz>

Livinský, O.; Kočík, R. 2003. Za prací do Česka. Praha: Infoservis společnosti Člověk v tísni při České televizi [online]. Dostupný z: $<$ http://www.infoservis.net>

Národni strategie boje proti obchodování s lidmi (2005-2007). 2005. Praha: Ministerstvo vnitra, Odbor bezpečnostní politiky. [online]. Dostupný z: <http://www.mvcr.cz/dokument/ 2005/strategie.pdf>

Pilotní výzkum prostředí obchodu s lidmi v České republice. 2005. Praha: IOM [online]. Dostupný z: <http://www.mvcr.cz>

Topinka, D. 2005. Instituce klientelismu na pozadi legality a nelegality. Praha: Multikulturní centrum [online]. Dostupný z: <http://www.migraceonline.cz $>$

Trávníková, B. 2004. Česká republika a nelegální migrace. Praha: Multikulturní centrum [online]. Dostupný z: <http://www.migraceonline.cz>

Výzkum obchodu s lidmi predevším za účelem nucené práce. 2005. NTERMUNDIA, o.p.s. [online]. Dostupný z: <http://www.migrace.cz>

Zpráva o situaci v oblasti migrace na území České republiky za rok 2004. 2005. Praha: MVČR [online]. Dostupný z: <http://www.mvcr.cz>

\section{Autor}

Daniel Topinka působí jako odborný asistent v Kabinetu interkulturních studií na Katedře sociologie a andragogiky Filozofické fakulty Univerzity Palackého v Olomouci. V rámci doktorandského programu oboru sociologie na Fakultě sociálních studií Masarykovy univerzity dokončuje disertační práci věnovanou integraci azylantů. Kontakt: d.topinka@volny.cz 